\title{
Prevalence of Asymptomatic Bacteriuria among the Pregnant Women Receiving Antenatal Care at Federal Medical Centre Owerri, Nigeria
}

\author{
Onuorah Samuel ${ }^{1, *}$, Ogbonna Victoria ${ }^{1}$, Obika Ifeanyi ${ }^{2}$ \\ ${ }^{1}$ Department of Applied Microbiology and Brewing, Nnamdi Azikiwe University Awka, Nigeria \\ ${ }^{2}$ Department of Zoology, Nnamdi Azikiwe University, Nigeria
}

Copyright $\mathrm{O} 2016$ by authors, all rights reserved. Authors agree that this article remains permanently open access under the terms of the Creative Commons Attribution License 4.0 International License

\begin{abstract}
The prevalence of asymptomatic bacteriuria among the pregnant women receiving antenatal care at Federal Medical Centre Owerri, Nigeria was studied using one hundred and forty urine samples from the pregnant women in the in-patient and out-patient departments. Thirty-five of the women had significant bacteriuria, with a prevalence rate of $25 \%$. The bacteria in the samples were Escherichia coli, Staphylococcus aureus, Pseudomonas aeruginosa and Proteus mirabilis. Escherichia coli occurred most frequently (40\%) while Pseudomonas aeruginosa had the lowest frequency of occurrence (14\%) in the samples. The infection was most prevalent among the women aged between 21 and 30 years (38.1\%) and lowest among those between 41 and 50 years of age $(9.4 \%)$. The prevalence was highest among the pregnant farmers and lowest among the pregnant civil servants in both the in-patient and out-patient departments. Pregnant women in the out-patient department had a higher prevalence than the women in the in-patient department. Pregnancy promotes the progression of asymptomatic to symptomatic bacteriuria with its consequences such as pyelonephritis, urinary tract infections and increased foetal mortality, therefore regular urine analysis of all pregnant women by certified health authorities is recommended.
\end{abstract}

Keywords Prevalence, Asymptomatic Bacteriuria, Pregnant Women, Antenatal Care, Medical Centre, Nigeria

\section{Introduction}

Bacteriuria refers to the presence of bacteria in urine. The upper urethra is the most frequent site of infection within the urinary tract but the entire system is always at risk of invasion by bacteria once one of the parts is infected. [1]. It is generally accepted that $10^{5}$ or more colony forming units of bacteria per milliliter of urine is significant bacetriuria whether the patient is symptomatic or asymptomatic $[2,3]$.

Asymptomatic bacteriuria is a condition in which urine culture reveals the presence of more than 100,000 bacteria per milliliter but without the patient showing symptoms of urinary tract infection. This is common during pregnancy and if untreated could lead to serious complications. Untreated asymptomatic bacteriuria is a risk factor for acute cystitis (40\%) and pyelonephritis (25-30\%) in pregnancy [4].

The apparent reduction in immunity of pregnant women appears to encourage the growth of both commensal and non-commensal microorganisms [4]. The physiological increase in plasma volume during pregnancy decreases urine concentration and up to $70 \%$ pregnant women develop glucouria, which encourages bacterial growth in the urine.

Pregnancy causes numerous changes in the woman's body. Hormonal and mechanical changes increase the risk of urinary stasis and vesicoureteral reflux. These changes including shortness of the urethra and difficulty with hygiene due to a distended belly, increase the frequency of urinary tract infections in pregnant women. Urinary tract infections are one of the most common bacterial infections during pregnancy [5].

Women with asymptomatic bacteriuria show a variable degree of local urinary immune response. Approximately one third to half of elderly women with asymptomatic bacteriuria have elevated antibody levels compared with non-bacteriuria women. Urinary cytokines have been shown to be more frequently present in women with asymptomatic bacteriuria [6].

Various researchers have reported the prevalence of asymptomatic bateriuria among pregnant women and their effect on the reduction in immunity [7]. Increased risk of infection of pregnant women and foetus as a result of asymptomatic bacteriuria has been reported [8]. Pregnancy enhances the progression from asymptomatic to symptomatic bacteriuria which could lead to pyelonephritis and obstetric outcomes such as prematurity, low birth weight and higher foetal mortality rates $[9,10,11]$. 
The adverse effects of undiagnosed asymptomatic bacteriuria on mother and child have made researchers to recommend routine urine culture for all pregnant women attending antenatal clinic to prevent mother and child from any form of complication that may arise due to infection $[8,12]$

In many hospitals in Nigeria, routine urine culture is not carried out on antenatal patients probably due to cost implications and time factor, instead many clinicians opt for the dipstick method for assessing urine in pregnant women [9]. However, the dipstick method cannot quantify the extent of infection in such patients as well as provide antimicrobial therapy which is usually seen in the case of culture [13] rather, the attention of health care providers is usually on the presence of glucose and protein in urine specimens with less attention on the possible asymptomatic infections. [11].

This study was carried out to determine the prevalence of asymptomatic bacteriuria among the pregnant women receiving antenatal care at Federal Medical Centre Owerri, Nigeria. It is hoped that the result of this study would aid the planners of the health care delivery system in Nigeria in the formulation of policies and programmes for the control of urinary tract infections especially among pregnant women.

\section{Materials and Methods}

\subsection{Samples Collection}

Mid-stream urine samples were obtained from one hundred and forty pregnant women receiving antenatal care at Federal Medical Centre Owerri, Nigeria between July and September, 2015. Seventy of the samples care from in-patient while the other seventy samples came from the out-patient department of the medical centre. The patients were aged between sixteen and fifty years. The pregnant women whose urine samples were examined were housewives, traders, farmers and civil servants. The women were in their second trimester of pregnancy and their oral consent was sought and obtained before the samples collection.

The samples were collected in sterile urine bottles by the patients in the morning of the day of investigation and conveyed to the laboratory on ice packs. The time taken for the samples to reach the laboratory was thirty minutes while analysis was carried out within two hours of samples collection. The samples were serially-diluted before use.

\subsection{Isolation of the Total Bacteria in the Urine Samples}

The spread plate technique was used with Cysteine Lactose Electrolyte Deficient (CLED) Agar as the culture medium. One milliliter of the serially-diluted urine sample $\left(10^{6}\right)$ was introduced with a sterile pipette into a sterile culture plate containing the medium and evenly spread with a sterile glass spreader. The medium had ketoconazole at a concentration of $0.05 \mathrm{mg} / \mathrm{ml}$ added to inhibit fungal growth. The plates were covered and incubated at $35^{\circ} \mathrm{C}$ for twenty four hours. The bacterial colonies that developed were subcultured on sterile nutrient agar (NA) plates and later stored on sterile NA slants for characterization and identification.

\subsection{Isolation of Total Coliform Bacteria}

One milliliter of the serially-diluted $\left(10^{6}\right)$ was spread uniformly on the surface of MacConkey's Agar contained in a petri dish. The plate had ketoconazole at a concentration of $0.05 \mathrm{mg} / \mathrm{ml}$ to inhibit fungal growth. Incubation was carried out in an inverted position at $35^{\circ} \mathrm{C}$ for 24 hours after which the coliform bacteria that developed were purified by repeated subculturing and later stored on sterile nutrient agar slants for characterization and identification.

\subsection{Isolation of Faecal Coliform Bacteria}

One milliliter of the serially-diluted sample $\left(10^{6}\right)$ was introduced onto the surface of eosin methylene blue agar contained in a petri dish. The petri dish also had ketoconazole at a concentration of $0.05 \mathrm{mg} / \mathrm{ml}$ added to inhibit fungal growth. The sample was evenly spread on the medium with a sterile wire loop. Incubation was carried out in an inverted position at $35^{\circ} \mathrm{C}$ for twenty four hours. The colonies that developed after incubation were subcultured on sterile nutrient agar plates and later stored on sterile NA slants for further tests.

\subsection{Characterization and Identification of the Isolates}

The morphological and biochemical characteristics of the isolates were determined. Gram staining, indole, coagulase, voges proskaeur, methyl red, citrate utilization, catalase, spore, carbohydrate fermentation and oxidase tests were performed as carried out by Onuorah et al [14]. The isolates were identified as described by Holt et al [15].

\subsection{Statistical Analysis of Data}

The data were analyzed using SPSS 19.0 window packages. Significance of the prevalence of asymptomatic bacteriuria was determined by chi-square test at $\mathrm{P}<0.05$.

\section{Results}

The urine samples obtained from one hundred and forty pregnant women receiving antenatal care at the in-patient and out-patient departments of Federal Medical Centre, Owerri, Nigeria were examined for asymptomatic bacteriuria. The prevalence of bacteriuria in the pregnant women is shown in Table 1. Thirty-five of the samples were found to contain bacterial cells in excess of $10^{5} / \mathrm{ml}$, indicating significant bacteriuria. 
Table 1. Prevalence of Asymptomatic Bacteriuria among the Pregnant Women

\begin{tabular}{|c|c|c|c|}
\hline $\begin{array}{c}\text { Pregnant } \\
\text { Women }\end{array}$ & $\begin{array}{c}\text { Number } \\
\text { Examined }\end{array}$ & $\begin{array}{c}\text { Number with } \\
\text { Asymptomatic } \\
\text { Bacteriuria }\end{array}$ & $\begin{array}{c}\text { Prevalence } \\
\text { (\%) }\end{array}$ \\
\hline $\begin{array}{c}\text { Out-Patient } \\
\text { Women }\end{array}$ & 70 & 21 & 15.0 \\
\hline $\begin{array}{c}\text { In-Patient } \\
\text { Women }\end{array}$ & 70 & 14 & 10.0 \\
\hline Total & 140 & 35 & 25.0 \\
\hline
\end{tabular}

The bacterial isolates from the urine samples of the pregnant women and their frequency of occurrence are shown in Table 2. They were mostly gram negative rods. Escherichia coli occurred most frequently (40\%), while Pseudomonas aeruginosa had the least frequency of occurrence $(14 \%)$.

Table 2. Bacterial Isolates from the Urine Samples of the Pregnant Women and their frequency of occurrence.

\begin{tabular}{|c|c|c|c|}
\hline Isolates & Identity & $\begin{array}{c}\text { Number } \\
\text { Isolated }\end{array}$ & $\begin{array}{c}\text { Frequency of } \\
\text { occurrence }\end{array}$ \\
\hline 1 & Escherichia coli & 20 & 40 \\
\hline 2 & $\begin{array}{c}\text { Staphylococcus } \\
\text { aureus }\end{array}$ & 15 & 30 \\
\hline 3 & $\begin{array}{c}\text { Pseudomonas } \\
\text { aeruginosa }\end{array}$ & 7 & 14 \\
\hline 4 & Proteus mirabilis & 8 & 16 \\
\hline
\end{tabular}

The occurrence of asymptomatic bacteriuria in the pregnant women according to the age groups is shown in Table 3. The occurrence was most in the women between 21 and 30 years of age $(38.1 \%)$ and lowest in those between 41 and 50 years $(9.4 \%)$.

Table 3. Occurrence of Asymptomatic Bacteriuria among the Pregnant Women According to the Age Groups

\begin{tabular}{|c|c|c|c|}
\hline $\begin{array}{c}\text { Age } \\
\text { Group }\end{array}$ & $\begin{array}{c}\text { Number } \\
\text { Examined }\end{array}$ & $\begin{array}{c}\text { Number with } \\
\text { Asymptomatic } \\
\text { Bacteriuria }\end{array}$ & $\begin{array}{c}\text { Percentage } \\
\text { Occurrence }\end{array}$ \\
\hline $16-20$ & 50 & 18 & 36.0 \\
\hline $21-30$ & 21 & 8 & 38.1 \\
\hline $31-40$ & 37 & 6 & 16.2 \\
\hline $41-50$ & 32 & 3 & 9.4 \\
\hline
\end{tabular}

The occurrence of asymptomatic bacteriuria according to the socio-economic status of the pregnant in-patient women is shown in Table 4. The occurrence was most among farmers $(27.6 \%)$ and lowest among the civil servants $(10.0 \%)$..

Table 4. Occurrence of Asymptomatic Bacteriuria According to the Socio-Economic Status of the In-Patient Pregnant Women

\begin{tabular}{|c|c|c|c|}
\hline $\begin{array}{c}\text { Social- } \\
\text { Economic } \\
\text { Status }\end{array}$ & $\begin{array}{c}\text { Number } \\
\text { Examined }\end{array}$ & $\begin{array}{c}\text { Number with } \\
\text { Asymptomatic } \\
\text { Bacteriuria }\end{array}$ & $\begin{array}{c}\text { Percentage } \\
\text { Occurrence }\end{array}$ \\
\hline Housewives & 23 & 3 & 13.0 \\
\hline Traders & 19 & 5 & 26.3 \\
\hline Farmers & 18 & 5 & 27.6 \\
\hline Civil Servants & 10 & 1 & 10.0 \\
\hline
\end{tabular}

The occurrence of asymptomatic bacteriuria according to the socio-economic status of the pregnant out-patient women is presented in Table 5. The occurrence was also highest among the pregnant farmers $(34.8 \%)$ and lowest among the pregnant civil servants $(26.7 \%)$

Table 5. Prevalence of Asymptomatic Bacteriuria According to the Socio-Economic Status of the Out-Patient Pregnant Women

\begin{tabular}{|c|c|c|c|}
\hline $\begin{array}{c}\text { Social- } \\
\text { Economic } \\
\text { Status }\end{array}$ & $\begin{array}{c}\text { Number } \\
\text { Examined }\end{array}$ & $\begin{array}{c}\text { Number with } \\
\text { Asymptomatic } \\
\text { Bacteriuria }\end{array}$ & $\begin{array}{c}\text { Percentage } \\
\text { Occurrence }\end{array}$ \\
\hline Housewives & 11 & 3 & 27.3 \\
\hline Traders & 21 & 6 & 28.6 \\
\hline Farmers & 23 & 8 & 34.8 \\
\hline Civil Servants & 15 & 4 & 26.7 \\
\hline
\end{tabular}

\section{Discussion}

In this work, out of the one hundred and forty urine samples from pregnant women in both the in-patient and out-patient departments of Federal Medical Centre Owerri, thirty-five showed significant bacteriuria, giving a prevalence rate of $25 \%$ (Table 1 ). The prevalence was higher in the pregnant women in the out-patient department than in the in-patient department. This may be due to the fact that the in-patient pregnant women were receiving adequate medical care than their out-patient counterparts.

The relatively high prevalence obtained in this work may have been influenced by time taken for the transportation of the samples from the collection point to the processing laboratory which could have encouraged the multiplication of the bacteria in such samples and poor personal hygiene of the women due to their distended stomachs. Atlas [13] reported that rural dwellage, socio-economic status, sex habit and personal hygiene do affect the prevalence of significant bacteriuria.

The bacterial isolates from the urine samples from the pregnant women were Escherichia coli, Staphylococcus aureus, Pseudomonas aeruginosa and Proteus mirabilis (Table 2). Ayoade at al [16] also isolated Staphylococcus aureus, Escherichia coli, Pseudomonas and Klebsiella in the urine samples of the university students with asymptomatic urinary tract infections they examined while Ugbogu et al [17] isolated Staphylococcus aureus, Proteus, Escherichia coli and Klebsiella from the urine samples of the pregnant women with asymptomatic bacteriuria in Aba, Abia State, Nigeria. Bloomberg et al [8] also isolated Staphylococcus aureus, Escherichia coli, Proteus and Pseudomonas from the urine samples of pregnant women in rural Tanzania.

A greater percentage of the positive cases were due to gram-negative rods indicating that they are the most predominant causative agents of urinary tract infections. This result is in agreement with the finding of Montgomerie [3] who reported that the higher incidence of gram-negative rods may be because they form a greater proportion of the 
microflora of the gastro intestinal tract. Orenstein and Wong [18] also reported the dominance of gram-negative organisms in the urine samples of the adults they examined. The presence of the gram-positive coccus, Staphylococcus aureus indicated that the gram-positive cocci are also causative agents of urinary tract infections. Their presence in low number may due to the fact that they are normal flora of the skin and hence form a lesser proportion of the microflora of the gastrointestinal tract.

Escherichia coli occurred most frequently (40\%), while Pseudomonas aeruginosa had the least frequency of occurrence (14\%) in the urine samples (Table 2). Ugbogu et al [17] however reported a frequency of isolation of $39.2 \%$, 9.8\%, 33.3\% and $17.6 \%$ for Staphylococcus aureus, Proteus, Escherichia coli and Klebsiella respectively in the urine samples they studied, while Bloomberg et al [8] isolated Staphylococcus (27.1\%), Escherichia coli (25.4\%), Proteus (10.2\%) and Pseudomonas (5.1\%) in the urine samples of the pregnant woman they examined. The variation in the frequency of isolation may be attributed to the nature of the samples, the period between collection and analysis of samples and the method of analysis.

Escherichia coli were the dominant bacterium isolated from the samples. This result agreed with the work of Richardson [19], Brooks [20] and Orenstein and Wong [18] regarding the dominance of Escherichia coli in the causation of urinary tract infections. Escherichia coli were the most common gram-negative rod isolated from the samples. The bacterial isolates came from the urinary bladder of the women as the samples were collected aseptically into sterile screw-capped bottles and also analyzed aseptically in a hygienic environment.

The prevalence of asymptomatic bacteriuria in the pregnant women was most in those between 21 and 30 years of age $(38.1 \%)$ and least in those between 41 and 50 years $(9.4 \%)$ of age (Table 3.). This result is in conformity with the work of Ahmad, [21] who reported that most of the female urinary tract infection patients with significant bacteriuria in Kashmir were between 21 and 30 years. Bloomberg et al [8], however reported that their urinary tract bacterial isolates were predominant in pregnant women between 31 and 35 years.

The occurrence of asymptomatic bacteriuria was most among the pregnant farmers (in-patient, 27.6\%, out-patient, $34.8 \%$ ). The occurrence was significantly higher in the pregnant farmers compared to other socio-economic classes (Table 4 and 5). This may be attributed to the poor hygiene level of the pregnant farmers. This result is in agreement with Bloomberg et al [8] who reported that pregnant farmers were mostly infected with urinary tract bacteria in rural Tanzania.

Asymptomatic bacteriuria was high among the pregnant woman studied $(25 \%)$. Routine urine tests should be carried out on all antenatal pregnant women in other to identify any unsuspecting infection. This will assist in the reduction of pregnancy-related maternal and obstetric complications.

\section{Conclusions}

This study showed that age and socio-economic status contributed tremendously to the prevalence of asymptomatic bacteriuria among the pregnant women whose urine samples were examined. The incidence was higher in the out-patients than the in-patients. Escherichia coli was the dominant bacterium isolated. Pregnant women are advised to consult qualified and experienced medical personnel for appropriate diagnosis, control and treatment of pregnancy-related urinary tract infections.

\section{REFERENCES}

[1] C.M. Kunin. Urinary Tract Infections in Females. Clinical Infectious Diseases, Vol. 18, No.1, 1-10, 1994. http://www.ncbi.nlm.nih.gov/pubmed/8054415.

[2] M.S. Najar, C.L. Saldanha, K.A. Banday. Approach to urinary tract infections. Indian Journal of Nephrology, Vol. 19, 129-139, 2009. http//www.indianjnephrol.org/text.asp?2009/ $19 / 4 / 129 / 59333$.

[3] J.Z. Montgomerie. Factors Virulence in Escherichia coli urinary tract infections. The journal of Infectious Diseases, Vol.137, No.5, 645-647, 1978. DOI:10.1093/infdis/137.5.64 5 .

[4] E.M. Scott, H.H. McGarrigle, G.C. Lacheline. The increase in Plasma and Saliva Cortisol Levels in Pregnancy is not due to the increase in corticosteroid-binding globulin levels. The Journal of Clinical Endocriminology and Metabolism, Vol. 71, No. 3, 639-644, 1990. DOI: 10.1210/jcem-71-3-639.

[5] W.E. Stamm, T.M. Hooton. Management of urinary tract infections in Adults. The New England Journal of Medicine, Vol. 329, 1328-1334, 1993.DOI:10.1056/NEJM1993102832 91808 .

[6] J. Akerele, P. Abhulimen, F. Okonofua. Prevalence of asymptomatic bacteriuria among pregnant women in Benin-City, Nigeria. Nigerian Journal of Obstetrics and Gynaecology, Vol.21, 141-144, 2001. http://dx.doi.org/10.10 $80 / 01443610020026038$.

[7] E.S. Amadi, O.B. Enemuo, C.J. Uneke, O.K. Nwosu, R.A. Onyeagba , O.C. Ugbogu. Asymptomatic bacteriuria among pregnant women in Abakaliki, Ebonyi State, Nigeria. Journal of Medical Sciences, Vol.7, 698-700, 2007. DOI:10.3923/jm s.2007.698.700.

[8] B. Bloomberg, B.E. Olsen, S.G. Hinderaker, N. Langeland, P. Gasheka, R. Jureen, G. Kvale, T. Midtvedt. Antimicrobial resistance in urinary bacterial isolates from pregnancy women in rural Tanzania. Implications for public health. Scandinavian Journal of Infectious Diseases, vol. 37, No.4, 262-268, 2005. http://www.ncbi.nlm.nih.gov/pubmed/15871 165.

[9] E.N. Lindsay. Screening for asymptomatic bacteriuria in pregnancy. Canadian Guide to Clinical Preventive Health Care, Vol. 10, 100-106, 2003.

[10] O.A. Olusanya, A. Ogunledun, T.A. Fakoya. Asymptomatic 
symptomatic bacteriuria among pregnant and non-pregnant women in Sagama, Nigeria. West African Journal of Medicine, Vol.12, 27-33, 1993.

[11] C.S. Kirklam, S. Harris, S. Grzybowski. Evidence based prenatal care: Part II; Third trimester care and prevention of infectious diseases. American Family Physician, Vol.71, No. 8, 1555-1560, 2005.

[12] N. Fatima, S. Ishrat. Frequency and risk factors of asymptomatic bacteriuria during pregnancy. Journal of the College of Physicians and Surgeons, Vol.16, No.4, 273-275, 2006. http://www.researchgate.net/publication/7156546.

[13] R.M. Atlas. Human disases caused by microorganisms. Microbiology: Fundamentals and Applications. The McGraw Hill Company Boston. Pp 614-620, 2004.

[14] S. Onuorah I., Obika M., Orji, F. Odibo. Microbial Contaminants in the Commercial Aviation fuel obtained from Benin-City Airport, Nigeria. Universal Journal of Microbiology Research, Vol.3, No.3, 31-35, 2015. DOI:10.13189/ujmr.2015.030301.

[15] J.G. Holt, N.R. Krieg, P.H.A. Staley, S.I. Williams (eds) Bergey's Manual and Determinative Bacteriology, $8^{\text {th }}$ edition. The Williams and Wilkins Company, Baltimore, U.S.A. Pp 70-720.
[16] F. Ayoade, D. Moro, O. Ebene. Prevalence and antimicrobial susceptibility pattern of asymptomatic urinary tract infections of bacterial and parasitic origins among University Students on redemption Camp, Ogu state, Nigeria Open Journal of Medical Microbiology, Vol.3, No.4, 219-226, 2013. doi: 10.4236/ojmm.2013.34033.

[17] O. Ugbogu, R.I. Ogbonnaya. Asymptomatic bacteriuria among pregnant women in Aba, Abia State, Nigeria. Nigerian Journal of Microbiology, Vol. 24, No.1, 2024-2027, 2010. http://www.researchgate.net/publication.234060632.

[18] R. Orenstein, E.S. Wong. Urinary tract infections in Adults. American Family Physician, Vol. 59, No.5, 1225-1234, 1999. http://www.aafp.org/afp/1999/0301/P1225.html.

[19] D.A. Richardson. Dysuria and Urinary tract infections Obstetrics and Gynaecology Clinical North America, Vol.17, No.4, 881-888, 1990. http://www.ncbi.nlm.nih.gov/pubmed/ 2092247

[20] F.G. Brooks, C.K. Carroll, S.J. Butel, A.S. Morse. Jawetz, Melnick and Alderberg's Medical Microbiology. The McGraw Hill Company Boston. Pp.253-255, 2007.

[21] S. Ahmad. Pattern of urinary tract infection in Kashmir and antimicrobial susceptibility. Bangladesh Medical Research Council Bulletin, Vol.38, No.3, 79-83, 2012.http://www.ncb i.nlm.nih.gov/pubmed/23540181. 